\title{
Control of Cladosporium echinulatum in carnation using bicarbonates and Trichoderma
}

\author{
Claudio Sandoval, Valeria Terreros, and Flavia Schiappacasse \\ Facultad de Ciencias Agrarias, Universidad de Talca, Casilla 747, Talca, Chile
}

\begin{abstract}
C. Sandoval, V. Terreros, and F. Schiappacasse. 2009. Control of Cladosporium echinulatum in carnation using bicarbonates and Trichoderma. Cien. Inv. Agr. 36(3):487-498. Carnations, Dianthus caryophyllus, have been cultivated in Chile for several decades as a cut flower crop. At the present time, floriculture occupies 2,124 ha, of which 180 ha are devoted to carnations. Almost all carnations produced are sold in the domestic market. Several diseases affect carnations, among them fairy-ring leaf spot (Cladosporium echinulatum), the most important foliar disease in Chile. Different control alternatives for fairy-ring spot were evaluated on the carnation cv. Sarinah in terms of disease incidence and severity. The study was performed in June-August 2003 with a commercial carnation planting in a greenhouse located in Champa $\left(33^{\circ}\right.$ $\left.49^{`} \mathrm{~S}, 70^{\circ} 45^{`} \mathrm{~W}\right)$ that in previous growing seasons reported a high incidence of fairy-ring leaf spot. The treatments included ammonium bicarbonate $\left(5 \mathrm{~g} \mathrm{~L}^{-1}\right)$, sodium bicarbonate $\left(5 \mathrm{~g} \mathrm{~L}^{-1}\right)$, ammonium bicarbonate + mineral oil Srpinguill $\left(5 \mathrm{~g} \mathrm{~L}^{-1}+10 \mathrm{~mL} \mathrm{~L}^{-1}\right)$, sodium bicarbonate + mineral oil Srpinguill $\left(5 \mathrm{~g} \mathrm{~L}^{-1}+10 \mathrm{~mL} \mathrm{~L}^{-1}\right)$, mineral oil Srpinguill $\left(10 \mathrm{~mL} \mathrm{~L}^{-1}\right)$, mancozeb $\left(2 \mathrm{~g} \mathrm{~L}^{-1}\right)$, copper oxichloride $\left(2 \mathrm{~g} \mathrm{~L}^{-1}\right)$, pentahydrated copper sulfate $\left(1 \mathrm{~mL} \mathrm{~L}^{-1}\right)$, Trichoderma virens strain Sherwood (Trichonativa) $\left(5 \mathrm{~mL} \mathrm{~L}^{-1}\right)$ and an untreated control. Based on the results obtained, the most effective treatments were sodium bicarbonate and T. virens. Mancozeb, copper oxichloride, sodium bicarbonate + mineral oil Springuill, ammonium bicarbonate, mineral oil Springuill and pentahydrated copper sulfate were ineffective in controlling carnation fairy-ring leaf spot.
\end{abstract}

Key words: Carnation, Cladosporium, Dianthus caryophyllus, foliar diseases, sodium bicarbonate, Trichoderma.

\section{Introduction}

According to the last agropecuarian census (ODEPA, 2007), there are 2,124 ha in Chile dedicated to floriculture. Of this total, 180 ha are covered with carnations (Dianthus caryophyllus L.), which are primarily cultivated for internal consumption as cut flowers.

Received 14 November 2008. Accepted 02 April 2009.

Corresponding author: fschiap@utalca.cl
In Chile, four foliar diseases in carnations have been identified (Latorre, 2004), and fairy-ring leaf spot, produced by Cladosporium echinulatum (Berk.) G.A. De Vries (tel. Mycosphaerella dianthi (C.C. Burt) Jorst.), is the most important (Figure 1). This pathogen causes a loss in quality and a reduction in the amount of harvested stems. It affects the aerial organs of the plant, especially leaves and flowers. In leaves, the manifestation begins with small purple spots, which limits commercialization (Cedeño and Carrero, 1997). According to Agrios (1997) and Latorre (2004), conidia are spread by wind, cultural practices, workers, diseased plants or infected harvest residues. 


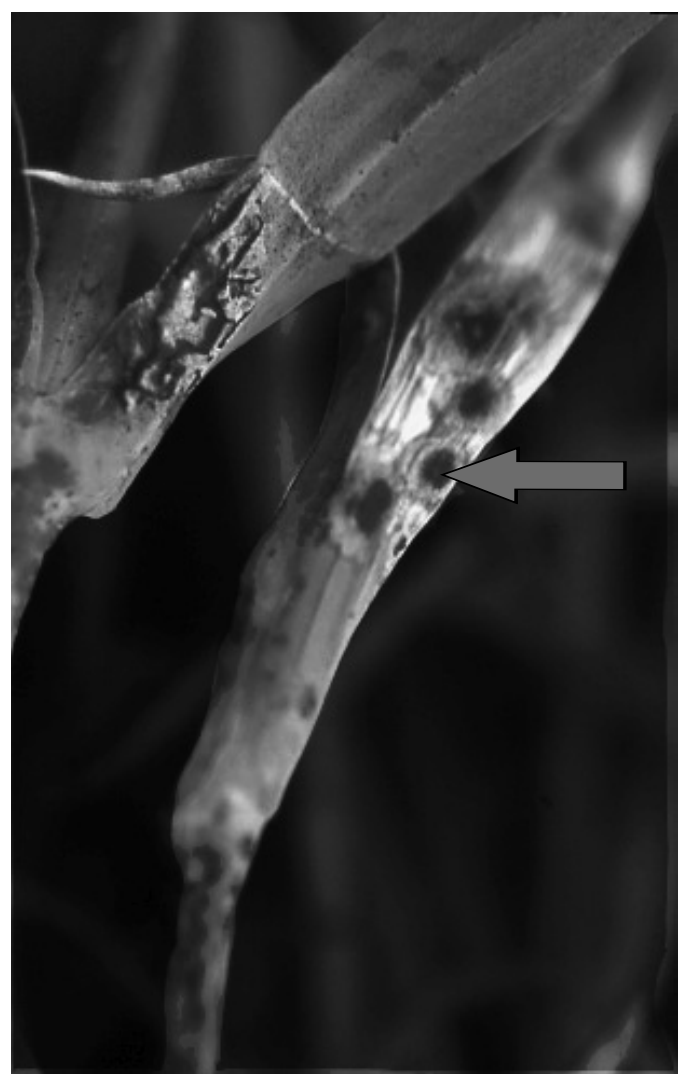

Figure 1. Carnation fairy-ring leaf spot caused by Cladosporium echinulatum. Notice the necrotic ring spots (arrow).

There are multiple options for fungicides. For example, mancozeb is recommended as a contact and preventive fungicide, and inhibits spore germination. Another option is pentahydrate copper sulfate, a systemic product with healing and preventative actions. This fungicide destroys the cell wall, inhibiting spore germination.

Ammonium bicarbonate, sodium bicarbonate and potassium carbonate have been shown to be effective in the control of foliar pathogens, both in vitro and in vivo in carnations and other ornamental species (Salazar, 2001; Palmer et al., 1997; Guzmán, 1994; Porter et al., 1993; Israel et al., 1993; Horst et al., 1992; Ziv and Zitter, 1992).

Fungi biocontrollers are considered a very ecological alternative, surviving for a long time as dormant structures that may germinate again. Therefore, periodic reinoculations are unnecessary (Wainwright, 1992). It has been proven that the method used by the fungus Trichoderma spp. to control pathogenic fungi is primarily through competition for food, space and predation (Cook and Baker, 1983). Trichonativa (Bionativa, San Javier, Chile) is a liquid formulation based on Trichoderma spp., with a concentration of $10^{10}$ conidia $\mathrm{mL}^{-1}$ plus hyphae pieces. It supplies active mycelium, allowing for faster and more efficient action against pathogens.

The objective of this study was to evaluate different alternatives to control carnation fairyring leaf spot under greenhouse conditions based on the incidence and severity levels of the disease for the different treatments.

\section{Materials and methods}

\section{Cultivation and place of evaluation}

The experiment took place in 2003 with a commercial carnation crop cv. Sarinah in a green-

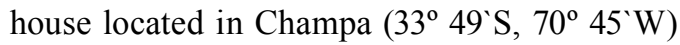
that had previously been infected by C. echinulatum.

\section{Treatments}

The treatments evaluated were as follows: (i) 5 $\mathrm{g} \mathrm{L}^{-1}$ of ammonium bicarbonate (Droguería Michelson, Santiago, Chile), (ii) $5 \mathrm{~g} \mathrm{~L}^{-1}$ of sodium bicarbonate (Droguería Michelson, Santiago, Chile), (iii) $5 \mathrm{~g} \mathrm{~L}^{-1}$ of ammonium bicarbonate in combination with $10 \mathrm{~mL} \mathrm{~L}^{-1}$ of mineral oil (formulated product, f.c.) Springuill (ANASAC S.A., Santiago, Chile), (iv) $5 \mathrm{~g} \mathrm{~L}^{-1}$ of sodium bicarbonate in combination with $10 \mathrm{~mL} \mathrm{~L}^{-1}$ of mineral oil (f.c.) Springuill, (v) $10 \mathrm{~mL} \mathrm{~L}^{-1}$ of mineral oil (f.c.) Springuill, (vi) $2 \mathrm{~g} \mathrm{~L}^{-1}$ mancozeb (Mancozeb $80 \%$ WP, Arysta Lifescience Chile S.A.), (vii) 2 $\mathrm{gL}^{-1}$ of copper oxychloride (Copper Oxychloride, Platte Chemical CO., U.A.P., Chile S.A.), (viii) 1 $\mathrm{mL} \mathrm{L}^{-1}$ of pentahydrate copper sulfate (Phyton27, Source Technology Biologicals, Inc., USA) and (ix) $5 \mathrm{~mL} \mathrm{~L}^{-1}$ of Trichoderma virens strain Sherwood (Trichonativa, Bionativa, San Javier, Chile). In addition, a control treatment without applications was included. 


\section{Application method}

The application of the fungicides was carried out using a 5 L back sprayer (Solo, Sindelfingen, Germany). The bicarbonates and the mineral oil alone and mixed were applied every 7 days for a month, while treatments with mancozeb, copper oxychloride and pentahydrate copper sulfate were applied every 10 days. T. virens strain Sherwood was applied twice every 15 days.

In all cases, the wetting was performed with 0.5 $\mathrm{L}$ of water for each $0.7 \mathrm{~m}^{2}$ plot up to pouring point. Product drift was avoided by using a $1 \mathrm{x}$ $1 \mathrm{~m}$ plastic barrier between experimental units during application.

\section{Evaluation}

Incidence and severity evaluations were conducted every 7 days for 60 days (July-August). Before the first application, a base evaluation of the state of each stem of the experimental plot was carried out. Therefore, the number of infected stems by plot $\left(\mathrm{I}_{1}\right)$ and the number of leaves with $C$. echinulatum wounds per stem $\left(\mathrm{I}_{2}\right)$ was determined. These were estimated according to the following equation:

$$
\begin{aligned}
& \text { Incidence } \\
& \text { (I) }=\frac{\text { infected stems or leaves per }}{\text { Total observed stems }}
\end{aligned}
$$

Calculation of the percent decrease in the incidence in stems and leaves was carried out between the first and the fourth evaluations and between the fourth and the final evaluations. This corresponds to the difference between the incidence values obtained 21 days after the start of the evaluations and 49 days after the start. In cases where the incidence value of the last evaluation date was higher than that of the initial date, a value of zero was assigned for the percent decrease.

Severity (S) was quantified according to the following equation (French and Hebert, 1980):

$$
\text { Severity (S) }=\frac{\mathrm{n}^{\mathrm{o}} \text { of active wounds }}{\mathrm{n}^{\mathrm{o}} \text { of stems }}
$$

Wounds were considered active when the presence of pathogen mycelium and conidia was verified using a $10 \mathrm{X}$ manual magnifier.

Severity was measured each time incidence was evaluated. Estimations of decreases in the severity of carnation ringspot were carried out using the same procedure described above for $\mathrm{I}_{1}$ and $\mathrm{I}_{2}$.

The rate of disease control was estimated based on the values of incidence or severity obtained on the first evaluation day (1 DDIE). This value represented $100 \%$ infection.

\section{Experimental design and statistical analysis}

A completely randomized experimental design was used that considered four repetitions and ten treatments. The experimental unit corresponded to two stems from $0.7 \mathrm{~m}^{2}$ plots of carnation plants cv. Sarinah. The results obtained were submitted to an analysis of variance. Comparisons of means were carried out using the Duncan test $(\mathrm{p} \leq 0.05)$. The percent values of incidence $\left(\mathrm{I}_{1}\right.$ and $\left.\mathrm{I}_{2}\right)$ were transformed to angular values $\left(\operatorname{arcsen}(\% / 100)^{1 / 2}\right)$ before conducting statistical analysis.

\section{Results}

The use of $T$. virens had no effect on the percent decrease of the stems infected in the first evaluation period. In the second period, sodium bicarbonate and $T$. virens stood out, both differing statistically from the remaining treatments (Table 1). In the second period of evaluation, T. virens with sodium bicarbonate treatment showed the greatest effect in terms of decreasing the number of leaves with $C$. echinulatum wounds. On the contrary, copper oxychloride, mancozeb, pentahydrate copper sulfate and ammonium bicarbonate alone and with mineral oil did not differ statistically from the control treatment (Table 1). 
Table 1. Effects of different control treatments with respect to the reduction in the incidence of carnation fairy-ring leaf spot (Cladosporium echinulatum) measured as \% of infected stems $\left(\mathrm{I}_{1}\right)$ and leaves with active lesions $\left(\mathrm{I}_{2}\right)$.

\begin{tabular}{|c|c|c|c|c|}
\hline \multirow[b]{3}{*}{ Treatments } & \multicolumn{4}{|c|}{ Incidence variation, $\%$} \\
\hline & \multicolumn{2}{|c|}{ Stems $^{1}$} & \multicolumn{2}{|c|}{ Leaves $^{2}$} \\
\hline & 0 to 21 days $^{3}$ & 21 to 49 days $^{4}$ & 0 to 21 days $^{3}$ & 21 to 49 days $^{4}$ \\
\hline Ammonium bicarbonate $(\mathrm{Ab}), 5 \mathrm{~g} \mathrm{~L}^{-1}$ & $4.3 \mathrm{~d}$ & $8.6 \mathrm{bc}$ & $3.8 \mathrm{de}$ & $0.0 \mathrm{~d}$ \\
\hline Sodium bicarbonate $(\mathrm{Sb}), 5 \mathrm{~g} \cdot \mathrm{L}^{-1}$ & $5.2 \mathrm{~cd}$ & $19.5 \mathrm{a}$ & $18.9 \mathrm{abc}$ & $21.0 \mathrm{a}$ \\
\hline $\mathrm{Ab}+$ mineral oil $5 \mathrm{gL}^{-1}+10 \mathrm{~mL} \cdot \mathrm{L}^{-1}$ & $17.0 \mathrm{ab}$ & $0.0 \mathrm{c}$ & $13.2 \mathrm{bc}$ & $0.0 \mathrm{~d}$ \\
\hline $\mathrm{Sb}+$ mineral oil $5 \mathrm{gL}^{-1}+10 \mathrm{~mL} \mathrm{~L}^{-1}$ & $8.6 \mathrm{~cd}$ & $8.2 \mathrm{bc}$ & $0.0 \mathrm{e}$ & $12.0 \mathrm{~b}$ \\
\hline Mineral oil $10 \mathrm{~mL} \cdot \mathrm{L}^{-1}$ & $6.1 \mathrm{~cd}$ & $6.5 \mathrm{bc}$ & $3.0 \mathrm{de}$ & $4.6 \mathrm{bc}$ \\
\hline Mancozeb $2 \mathrm{~g} \mathrm{~L}^{-1}$ & $20.9 \mathrm{a}$ & $0.0 \mathrm{c}$ & $9.1 \mathrm{~d}$ & $0.0 \mathrm{~d}$ \\
\hline Copper oxichloride $2 \mathrm{~g} \mathrm{~L}^{-1}$ & $17.5 \mathrm{ab}$ & $0.0 \mathrm{c}$ & $26.3 \mathrm{a}$ & $2.3 \mathrm{~cd}$ \\
\hline Pentahydrated copper sulfate $1 \mathrm{~mL} \mathrm{~L}^{-1}$ & $13.8 \mathrm{bc}$ & $0.1 \mathrm{~b}$ & $3.2 \mathrm{de}$ & $4.3 \mathrm{bc}$ \\
\hline T. virens strain Sherwood $5 \mathrm{~mL} \mathrm{~L}^{-1}$ & $0.0 \mathrm{~d}$ & $21.5 \mathrm{a}$ & $0.0 \mathrm{e}$ & $27.5 \mathrm{a}$ \\
\hline Control & $0.0 \mathrm{~d}$ & $0.0 \mathrm{c}$ & $0.0 \mathrm{e}$ & $0.0 \mathrm{~d}$ \\
\hline Significance & $* 5$ & $* * 5$ & $*$ & $* *$ \\
\hline
\end{tabular}

${ }^{1}$ Percentage of stems with fairy-ring leaf spot lesions.

${ }^{2}$ Percentage of leaves with fairy-ring leaf spot lesions in two stems. Means in the same column followed by the same letter are not statistically different according to the Duncan test $(\mathrm{p}=0.05)$.

${ }^{3}$ Period between the first and the fourth evaluation.

${ }^{4}$ Period between the fourth and the last evaluation.

$5 * *$ highly significant $\mathrm{p} \leq 0.01 ; *$ significant $\mathrm{p} \leq 0.05$.

In decreasing the number of active wounds, within the first evaluation period ( 0 to 21 days post-application) copper oxychloride, sodium bicarbonate and ammonium bicarbonate plus mineral oil were all statistically similar to one another. The remaining treatments did not differ statistically from the control $(\mathrm{p} \leq 0.05)$. In the second evaluation period, between days 21 to 49 post-application, $T$. virens was shown to be the most effective treatment in terms of decreasing the number of active wounds. The differences were shown to be highly statistically significant $(p \leq 0.01)$ with respect to the rest of the treatments, which did not differ statistically from the control treatment (Table 2).

Table 2. Effects of different treatments with respect to reductions in active Cladosporium echinulatum lesions in a commercial carnation planting.

\begin{tabular}{|c|c|c|}
\hline \multirow[b]{2}{*}{ Treatments } & \multicolumn{2}{|c|}{ Disease severity ${ }^{1}$ after } \\
\hline & $\begin{array}{l}0 \text { to } 21 \\
\text { days }^{2}\end{array}$ & $\begin{array}{l}21 \text { to } 49 \\
\text { days }^{3}\end{array}$ \\
\hline Ammonium bicarbonate $(\mathrm{Ab}), 5 \mathrm{~g} \mathrm{~L}^{-1}$ & $3.0 \mathrm{bc}$ & $2.0 \mathrm{~b}$ \\
\hline Sodium bicarbonate $(\mathrm{Sb}), 5 \mathrm{~g} \mathrm{~L}^{-1}$ & $8.0 \mathrm{ab}$ & $7.0 \mathrm{~b}$ \\
\hline $\mathrm{Ab}+$ mineral oil, $5 \mathrm{gL}^{-1}+10 \mathrm{~mL} \mathrm{~L}^{-1}$ & $7.0 \mathrm{ab}$ & $1.0 \mathrm{~b}$ \\
\hline $\mathrm{Sb}+$ mineral oil, $5 \mathrm{gL}^{-1}+10 \mathrm{~mL} \mathrm{~L}^{-1}$ & $3.0 \mathrm{bc}$ & $0.0 \mathrm{~b}$ \\
\hline Mineral oil, $10 \mathrm{~mL} \mathrm{~L}^{-1}$ & $4.0 \mathrm{bc}$ & $2.0 \mathrm{~b}$ \\
\hline Mancozeb, $2 \mathrm{~g} \mathrm{~L}^{-1}$ & $5.0 \mathrm{bc}$ & $0.0 \mathrm{~b}$ \\
\hline Copper oxichloride, $2 \mathrm{~g} \mathrm{~L}^{-1}$ & $11.0 \mathrm{a}$ & $1.0 \mathrm{~b}$ \\
\hline Pentahydrated copper sulfate, $1 \mathrm{~mL} \mathrm{~L}^{-1}$ & $0.0 \mathrm{c}$ & $1.0 \mathrm{~b}$ \\
\hline T. virens strain Sherwood, $5 \mathrm{~mL} \mathrm{~L}^{-1}$ & $1.0 \mathrm{c}$ & $16.0 \mathrm{a}$ \\
\hline Control & $0.0 \mathrm{c}$ & $0.0 \mathrm{~b}$ \\
\hline Significance & $* 4$ & $* * 4$ \\
\hline \multicolumn{3}{|c|}{$\begin{array}{l}{ }^{1} \text { Average of active lesions (with presence of mycelium or conidia) in two } \\
\text { stems. Means in the same column followed by the same letter are not } \\
\text { statistically different according to the Duncan test }(\mathrm{p}=0.05) \text {. } \\
\text { }{ }^{2} \text { Period between the first and the fourth evaluation. } \\
{ }^{3} \text { Period between the fourth and the last evaluation. } \\
{ }^{4 * *} \text { highly significant } \mathrm{p} \leq 0.01 ; * \text { significant } \mathrm{p} \leq 0.05 \text {. }\end{array}$} \\
\hline
\end{tabular}


In the first evaluation, carried out before the first applications of the products, there were no significant differences between plots with regard to the number of stems infected in relation to the total $\left(\mathrm{I}_{1}\right)$ (Table 3). However, in the final evaluation, sodium bicarbonate was found to be the most effective treatment in terms of the number of diseased stems, and was statistically similar to treatment with $T$. virens. $T$. virens treatment did not differ from the treatments with pentahydrate copper sulfate, copper oxychloride and ammonium bicarbonate plus mineral oil. The carnation plants treated with mancozeb, mineral oil, sodium bicarbonate plus oil and ammonium bicarbonate presented the highest incidence values of the disease at the end of the test, which were not statistically different from the control treatment.

Table 3. Stems with fairy-ring leaf spot (Cladosporium echinulatum) lesions on carnations $\left(\mathrm{I}_{1}\right)$ at the beginning and the end of the evaluations for nine different alternative control treatments.

\begin{tabular}{|c|c|c|c|}
\hline Treatments & $\begin{array}{l}\text { First evaluation }{ }^{1} \\
\%\end{array}$ & $\begin{array}{l}\text { Last evaluation }{ }^{2} \\
\%\end{array}$ & $\begin{array}{l}\text { Control rate } \\
\%\end{array}$ \\
\hline Ammonium bicarbonate $(\mathrm{Ab}), 5 \mathrm{~g} \mathrm{~L}^{-1}$ & 97.3 & 89.0 cde & 8.5 \\
\hline Sodium bicarbonate (Sb), $5 \mathrm{~g} \mathrm{~L}^{-1}$ & 92.0 & $72.5 \mathrm{a}$ & 21 \\
\hline $\mathrm{Ab}+$ mineral oil $5 \mathrm{~g} \mathrm{~L}^{-1}+10 \mathrm{~mL} \mathrm{~L}^{-1}$ & 89.5 & $81.4 \mathrm{~b}$ & 9.0 \\
\hline $\mathrm{Sb}+$ mineral oil $5 \mathrm{gL} \mathrm{L}^{-1}+10 \mathrm{~mL} \mathrm{~L}^{-1}$ & 100.0 & 90.0 cde & 10.0 \\
\hline Mineral oil $10 \mathrm{~mL} \mathrm{~L}^{-1}$ & 96.3 & $94.3 \mathrm{e}$ & 2.0 \\
\hline Mancozeb $2 \mathrm{~g} \mathrm{~L}^{-1}$ & 100.0 & $90.8 \mathrm{de}$ & 9.2 \\
\hline Copper oxichloride $2 \mathrm{~g} \mathrm{~L}^{-1}$ & 88.0 & $86.3 \mathrm{bcd}$ & 1.9 \\
\hline Pentahydrated copper sulfate $1 \mathrm{~mL} \mathrm{~L}^{-1}$ & 94.8 & $87.3 \mathrm{bcd}$ & 7.9 \\
\hline T. virens strain Sherwood $5 \mathrm{~mL} \mathrm{~L}^{-1}$ & 93.5 & $83.5 \mathrm{ab}$ & 10.7 \\
\hline Control & 97.3 & $100.0 \mathrm{f}$ & \\
\hline Significance & $\mathrm{ns}^{4}$ & $* * 4$ & \\
\hline
\end{tabular}

Means followed by the same letter in the same column are not statistically different according to the Duncan test $(\mathrm{p}=0.05)$

${ }^{1}$ Evaluation at the beginning of the experiment

${ }^{2}$ Evaluation at the end of the experiment.

${ }^{3} 100$ - (Incidence at the last evaluation / Incidence at the first evaluation) $* 100$.

${ }^{4} \mathrm{~ns}=$ not significant; $* *$ highly significant at $\mathrm{p} \leq 0.01$.

At the beginning of the experiment, the average percentage of wounded leaves with respect to the total for two stems $\left(\mathrm{I}_{2}\right)$ did not present significant differences among treatments, with all of the experimental plots showing similar percentages of carnation leaves with active wounds. On the contrary, in the evaluations conducted at the end of the test, sodium bicarbonate showed the highest control rate for the disease $(63 \%)$, followed by $T$. virens (38\%). However, the control rate of $\mathrm{I}_{2}$ was low. Six of the nine evaluated products showed percentages lower than $25 \%$ (Table 4 ). 
Table 4. Leaves with fairy-ring leaf spot (Cladosporium echinulatum) lesions on two carnation stems $\left(\mathrm{I}_{2}\right)$, at the beginning and the end of the evaluations for nine different alternative control treatments.

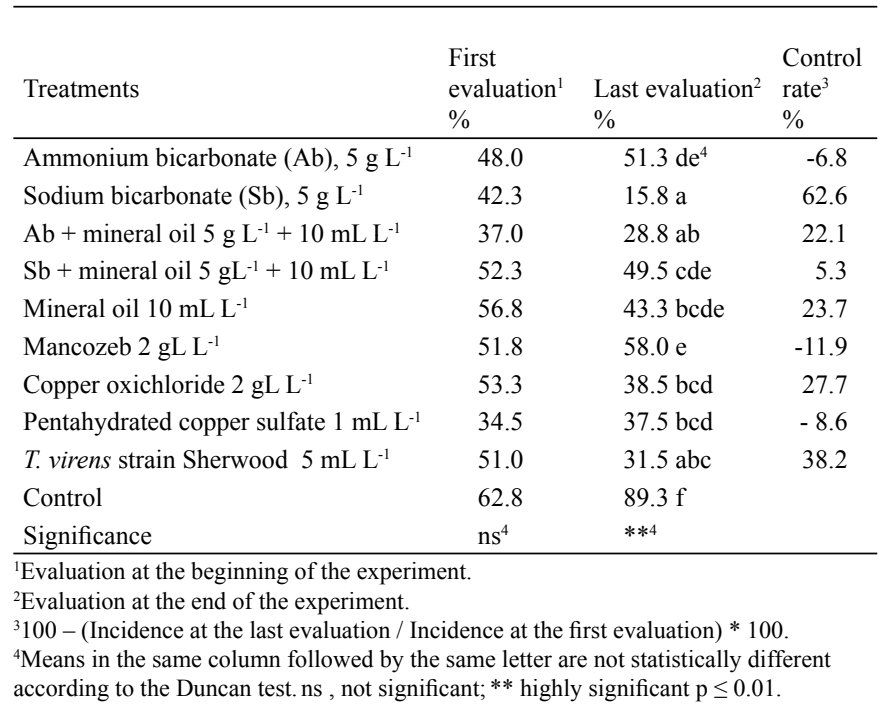

Sodium bicarbonate and T. virens presented control rates for disease severity of $74 \%$ and $44 \%$, respectively, expressed as the number of active wounds in leaves. The treatments with mancoz- eb, pentahydrate copper sulfate and ammonium bicarbonate had no effect on the control of $C$. echinulatum active wounds, and were not different from the control treatment (Table 5).

Table 5. Numbers of active lesions ${ }^{1}$ at the beginning and end of experiments evaluating different control alternatives for carnation fairy-ring leaf spot (Cladosporium echinulatum).

\begin{tabular}{|c|c|c|c|}
\hline Treatments & $\begin{array}{l}\text { First } \\
\text { evaluation }{ }^{2} \\
\%\end{array}$ & $\begin{array}{l}\text { Last evaluation }{ }^{3} \\
\%\end{array}$ & $\begin{array}{l}\text { Control } \\
\text { rate } \\
\%\end{array}$ \\
\hline Ammonium bicarbonate $(\mathrm{Ab}), 5 \mathrm{gL} \mathrm{L}^{-1}$ & 17 & $21 \mathrm{~cd}^{4}$ & -20 \\
\hline Sodium bicarbonate (Sb), $5 \mathrm{~g} \mathrm{~L}^{-1}$ & 21 & $6 \mathrm{a}$ & 74 \\
\hline $\mathrm{Ab}+$ mineral oil $5 \mathrm{gL}^{-1}+10 \mathrm{~mL} \mathrm{~L}^{-1}$ & 14 & $9 \mathrm{ab}$ & 35 \\
\hline $\mathrm{Sb}+$ mineral oil $5 \mathrm{gL}^{-1}+10 \mathrm{~mL} \mathrm{~L}^{-1}$ & 18 & $21 \mathrm{~cd}$ & -17 \\
\hline Mineral oil $10 \mathrm{~mL} \mathrm{~L}^{-1}$ & 20 & $17 \mathrm{bc}$ & 16 \\
\hline Mancozeb $2 \mathrm{~g} \mathrm{~L}^{-1}$ & 19 & $30 \mathrm{~d}$ & -55 \\
\hline Copper oxichloride $2 \mathrm{~g} \mathrm{~L}^{-1}$ & 19 & $15 \mathrm{bc}$ & 24 \\
\hline Pentahydrated copper sulfate $1 \mathrm{~mL} \mathrm{~L}^{-1}$ & 9 & $12 \mathrm{bc}$ & -32 \\
\hline T. virens strain Sherwood $5 \mathrm{~mL} \mathrm{~L}^{-1}$ & 19 & $11 \mathrm{abc}$ & 44 \\
\hline Control & 20 & $42 \mathrm{e}$ & \\
\hline Significance & $\mathrm{ns}^{4}$ & $* * 4$ & \\
\hline
\end{tabular}

${ }^{1}$ Average of active lesions (with presence of mycelium or conidia) in two stems.

${ }^{2}$ Evaluation at the beginning of the experiment.

${ }^{3}$ Evaluation at the end of the experiment.

${ }^{4}$ Means in the same column followed by the same letter are not statistically different according to the Duncan test. ns, not significant; $* *$ highly significant $\mathrm{p} \leq 0.01$. 


\section{Discussion}

All of the treatments had some effect on fairyring leaf spot control, differing statistically from the incidence and severity obtained in the control treatment. However, the most effective were sodium bicarbonate and T. virens. They presented the highest decrease rates with respect to $I_{1}, I_{2}$ and severity (Tables 2, 3, and 4).

Although sodium bicarbonate acted effectively to control the pathogen in the first five weeks of the test, from day 35 after the start of the applications, no effect was observed with respect to a decrease in the number of active wounds. This indicates the need for weekly application of the product; presumably, the disease can reach levels of incidence and severity close to zero (Figure 2).
On the other hand, when comparing the effects of ammonium bicarbonate in controlling C. echinulatum to its effects against other pathogens evaluated in other tests, it seems quite ineffective. In celery (Apium graveolens var. secalinum), ammonium bicarbonate was the most effective product in septoria control (Septoria apiicola) in vitro, exceeding sodium bicarbonate used at 1.0, 0.5 and $0.25 \%$ concentrations (Salazar, 2001). Similar results were found by Ziv and Zitter (1992) in the control of disease agents of horticultural species such as Sphaerotheca fuliginea, Didymella bryoniae, Alternaria cucumerina and Ulocladium cucurbitae when using ammonium bicarbonate at $1 \%(\mathrm{p} / \mathrm{v})$.

Ammonium bicarbonate plus mineral oil seems to be more effective than sodium bicarbonate mixed with mineral oil. This was evident by the lack of healing activity of sodium bicarbonate

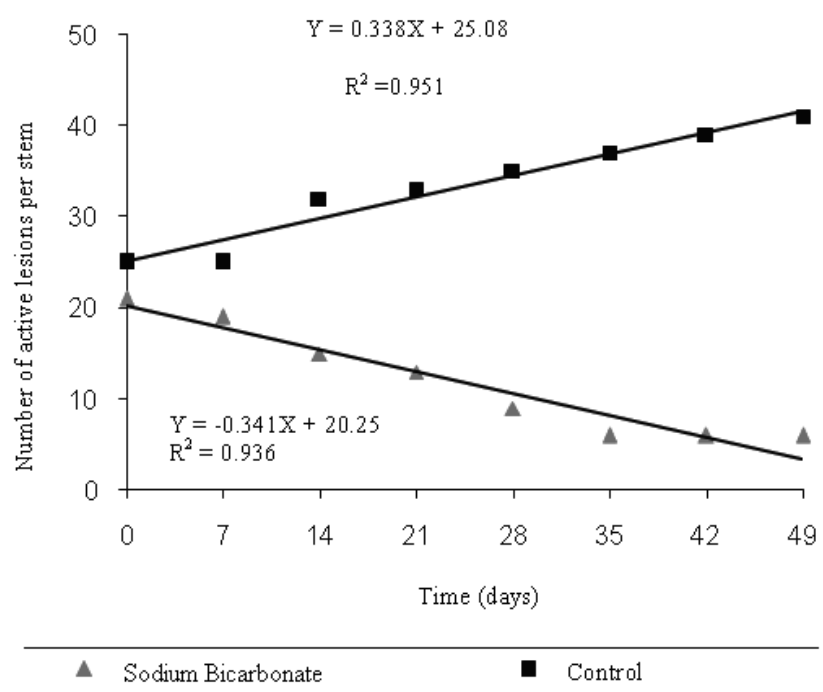

Figure 2. Variation during the experiment, in the number of fairy-ring leaf spot active lesions for carnation plants sprayed with bicarbonate and for untreated plants. 
plus mineral oil. However, it is noteworthy that sodium bicarbonate and mineral oil at $0.01 \%$ $(\mathrm{v} / \mathrm{v})$ alone or combined reduced the incidence of carnation fairy-ring leaf spot, yielding a better effect when sodium bicarbonate was applied separately. This conflicts with studies by Horst et al. (1992) on the control of fungal diseases in ornamental plants with bicarbonates in Rosa spp. and Euonymus japonica. Horst et al. (1992) made weekly applications of sodium bicarbonate at $0.063 \mathrm{M}$ and Sunspray ultrafine mineral oil at $1 \%(\mathrm{v} / \mathrm{v})$ and reduced the incidence of both diseases, obtaining a better effect when applied together. The difference may be explained by the fact that the mineral oil used in this experiment did not have the ultra-refining features of the Sunspray mineral oil.

On the other hand, the bicarbonates with mineral oil used for the C. echinulatum control created spots on carnation leaves.

Guzman (1994) and Salazar (2001) attributed the low healing activity showed by bicarbonates to their lack of a systemic effect and low or null translocation capacity. Accordingly to that, these products act only as preventive fungicides.

Regardless of the aforementioned study, Horst et al. (1992) and Ziv and Hagilady (1993) indicate the healing actions of bicarbonates on powdery mildew in Rosa spp. and Euonymus spp. These effects may be due to the corporeal structures of the fungus causing the disease, which are more superficially exposed to the actions of these products. In the present experiment, although all of the products were applied on both faces of the carnation leaves, the only products that caused wound healing on the upper sides and undersides of the leaves were the bicarbonates and the biocontroller T. virens strain Sherwood. Accordingly, bicarbonates would have healing effects on C. echinulatum that could be extrapolated to other fungi with superficial structures, such as Penicillium and Botrytis. The plant leaves where the other treatments were applied presented active wounds on both faces and constant sporulation, with masses of mycelia and conidia.

The mode of action of the bicarbonates in the control of phytopathogen fungi is still unknown, as stated by Horst et al. (1992), Ziv and Zitter (1992), Ziv and Hagilady (1993), Guzmán (1994) and Salazar (2001). The fungicide action could be due to a perturbation of the optimal $\mathrm{pH}$ for conidia germination and continued growth of the germinal tube of the C. echinulatum fungus.

Guzmán (1994) points out that the inhibition of germination caused by bicarbonates in in vitro solutions could be associated with high levels of $\mathrm{HCO}_{3}-$ or $\mathrm{CO}_{3}=$ ions, which could have fungicidal effects (Punja and Grogan, 1987).

On the other hand, the limited controlling effect of mancozeb is clear when the severity levels at the beginning and end of the test are considered. The same is observed with copper oxychloride and pentahydrate copper sulfate. However, copper oxychloride reduced the wounds by $23.6 \%$, making it more effective than mancozeb and pentahydrate copper sulfate for disease control, perhaps due to the greater residual effect of this product (Table 5).

According to the results, the biological controller was a good control alternative. An important aspect to consider when including this controller as part of an integrated pest management program is the mode of action, primarily competition. Once the biocontroller is applied, Trichoderma sp. propagules develop abundantly, superficially colonizing the plant tissues and competing for space with the fungus $C$. echinulatum.

In addition to this mode of action, mycoparasitism has been described, where certain enzymes could be involved, such as $\beta-1,3$ gluconase, lipase and proteolases, that are liberated into the environment by Trichoderma sp. and destroy the structural components of the pathogen (Elad et al., 1982).

With regard to the mycoparasitism, it is clear that the earlier the antagonist is applied to the host, the better is the control achieved. Hong et al. (1998), Cook and Baker (1989) indicate that the period between pathogen establishment and further sporulation corresponds to the most vulnerable stage for the pathogen to be displaced by the antagonist. In addition, by applying the inoculum of the biocontroller agent before the pathogen propagules are formed or spread, more efficient 
control can be achieved because the antagonist reaches a higher inoculum concentration when the pathogen has not yet reached high sporulation. This could explain why the control of $C$. echinulatum using $T$. virens strain Sherwood was efficient only from 28 days after the applications began, showing a strong rate of severity decrease after that point (Figure 2). In fact, the daily decrease in disease severity from that time was equal to 0.8 active wounds per day. Therefore, it is of interest to plan a strategy for disease control using the native strain Sherwood by considering preventive applications of the biocontroller from a month before the appearance of the predisposing conditions for the development of C. echinulatum. However, even under the conditions of this test, T. virens strain Sherwood was able to control the damage caused by the pathogen, presenting a healing effect on the active wounds of C. echinulatum on carnation leaves.

These results confirm statements by Cook and Baker (1989) and Chet (1987), who point out that Trichoderma is able to efficiently control a large number of diseases.

Figure 3 shows how the control treatment and the treatment with $T$. virens strain Sherwood presented similar behaviors in the first month ( 0 a 28 days). However, the control presented a sustained rate of increase in the number of active wounds per stem $\left(0.34\right.$ wounds stem ${ }^{-1}$ day $\left.^{-1}\right)$. great extent the production of carnation flowers due to its fast dissemination and aggressiveness under greenhouse conditions. Therefore, the costs that arise when applying sodium bicarbonate or $T$. virens Strain Sherwood (data not presented) are justified if the lower profitability obtained with carnation cultivation infected with C. echinulatum is considered.

Accordingly, when there are predisposing conditions for disease development in the months of June, July and August, applications of sodium bicarbonate and T. virens strain Sherwood are an efficient control strategy to prevent infection by $C$. echinulatum in carnations.

The best treatments to control carnation ringspot, caused by the fungus $C$. echinulatum, were sodium bicarbonate and $T$. virens strain Sherwood. Both presented the lowest indexes of incidence and severity of the disease.

Sodium bicarbonate showed an effective control of $C$. echinulatum until 35 days after the start of the applications, which indicates a residual period of the product of seven days.

The biological controller T. virens strain Sherwoood demonstrated effective control of the pathogen from the fourth week after the applications were initiated. Therefore, preventive applications must begin a month before the pre-

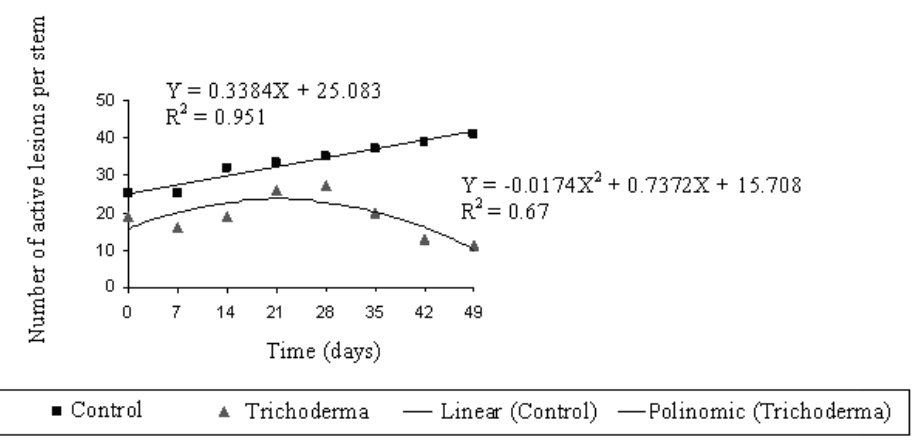

Figure 3. Variation during the experiment, in the number of fairy-ring leaf spot active lesions for carnation plants sprayed with Trichoderma virens and untreated plants.

It is noteworthy that the economic damage produced by C. echinulatum is high, reaching close to $60 \%$ (data not presented) and restricting to a disposing conditions for fungus development occur. 
Carnation plants treated with mancozeb, copper oxychloride, sodium bicarbonate plus oil, ammonium bicarbonate, mineral oil and pen- tahydrate copper sulfate presented the highest values of incidence and severity of the disease at the end of the experiment.

\section{Resumen}

C. Sandoval, V. Terreros y F. Schiappacasse. 2009. Control de Cladosporium echinulatum en clavel mediante el uso de bicarbonatos y Trichoderma. Cien. Inv. Agr. 36(3):487-498. El clavel, Dianthus caryophyllus, ha sido cultivado en Chile para producción de flores de corte desde hace varías décadas. Existen actualmente 2124 ha dedicadas a la floricultura, de las cuales 180 ha son de clavel. Prácticamente toda la producción de esta especie se comercializa en el mercado interno. Numerosas son las enfermedades que afectan su cultivo, siendo Cladosporium echinulatum el agente causal de la mancha foliar (mancha anular) más importante en esta especie. Se evaluaron distintas alternativas de control de esta patología en clavel cv. Sarinah, determinándose incidencia y severidad de la enfermedad en las plantas. El estudio se realizó en junio-agosto de 2003, en un plantel comercial bajo invernadero, ubicado en la localidad de Champa (33 $49^{`}$ Latitud Sur, $70^{\circ} 45^{`}$ Longitud Oeste), el cual tenía antecedentes de una alta incidencia de mancha anular. Los tratamientos fueron: bicarbonato de amonio $\left(5 \mathrm{~g} \mathrm{~L}^{-1}\right)$, bicarbonato de sodio $\left(5 \mathrm{gL}^{-1}\right)$, bicarbonato de amonio + aceite mineral Springuill $\left(5 \mathrm{gL}^{-1}+10\right.$ $\left.\mathrm{mLL}^{-1}\right)$, bicarbonato de sodio + aceite mineral Springuill $\left(5 \mathrm{gL}^{-1}+10 \mathrm{mLL}^{-1}\right)$, aceite mineral Springuill $\left(10 \mathrm{mLL}^{-1}\right)$, Mancozeb $\left(2 \mathrm{gL}^{-1}\right)$, Oxicloruro de Cobre $\left(2 \mathrm{gL}^{-1}\right)$, Sulfato de cobre pentahidratado (Phyton-27) (1 mLL $\left.\mathrm{mL}^{-1}\right)$, Trichoderma virens cepa Sherwood (Trichonativa) ( $\left.5 \mathrm{mLL}^{-1}\right)$, y el testigo (sin aplicación). Los resultados indicaron que los tratamientos más efectivos en el control de la enfermedad fueron bicarbonato de sodio y Trichoderma virens cepa Sherwood, presentando las mayores tasas de disminución de incidencia (varas enfermas y hojas con lesión) y severidad (lesiones activas por vara). Las plantas tratadas con mancozeb, oxicloruro de cobre, bicarbonato de sodio + aceite mineral Springuill, bicarbonato de amonio, aceite mineral Springuill y Sulfato de cobre pentahidratado presentaron los valores de incidencia y severidad de la enfermedad más altos, al final del experimento.

Palabras clave: Bicarbonato, Cladosporium, clavel, enfermedades foliares, Trichoderma.

\section{Referencias}

AFIPA-IMPPA-SAG. 2002-2003. Manual Fitosanitario. Fundación para el desarrollo frutícola. Servicios de Impresión Láser. Santiago, Chile.1214 p.

Agrios, G. 2005. Plant Pathology (5th Edition). Elsevier Academic Press, San Diego, California. USA. 948 pp.

Cedeño, L., and C. Carrero. 1997. Cladosporium echinulatum, causante de manchas en hojas y flores del clavel en Mérida, Venezuela. Revista Forestal Venezolana 41:91-92.

Chet, I. 1987. Innovative approaches to plant disease control. John Wiley and Sons, NY, USA. 372 p.

Cook, R. J., and K.F. Baker. 1989. The nature and practice of biological control of plant pathogens. American Phytopathological Society. St. Paul, MN, USA. 539 p.

Elad, Y., Y. Chet, and Y. Henis. 1982. Degradation of plant pathogenic fungi by Trichoderma harzianum. Canadian Journal of Microbiology 28:719-725.

French, E. R., y T.T. Hebert. 1980. Métodos de investigación fitopatológica. Editorial IICA, San José, Costa Rica. 289 p.

Guzmán, P. 1994. Control de la roya del clavel a través del uso de distintos tipos de bicarbonatos y carbonato en mezcla con aceite mineral. Tesis de grado. Escuela de Agronomía, Facultad de Ciencias, Agrarias Universidad de Talca. Talca, Chile. 84 p.

Hong, C., T. Michailides, and B. Holtz. 1998. Effecs 
of wounding, inoculum density, and biological control agents on postharvest brown rot of stone fruits. Plant Disease 82:1210-1216.

Horst, R. K., S.O. Kawamoto, and L.L. Porter. 1992. Effect of sodium bicarbonate and oils on the control of powdery mildew and black spot of roses. Plant Disease 76:247-251.

Israel, H. W., S.W. Ingalls, L.L. Porter, and R.K. Horst. 1993. Control of powdery mildew of rose with bicarbonates. A qualitative microscopic study of erradication. Phytopathology 93:244 (Abstract).

Latorre, B. 2004. Enfermedades de las Plantas Cultivadas. Sexta ed. Ediciones Universidad Católica de Chile. Santiago, Chile. 638 p.

ODEPA. 2007. Flores de corte (en línea). Chile. Avalaible online at http://www.odepa.gob.cl. (Accessed: November, 2008).

Porter, L. L., R. K. Horst, and H.W. Israel. 1993. Control of powdery mildew of rose with bicarbonates: II. A quantitative influence on fungal structures. Phytopathology 83:246 (Abstract).

Palmer, C. L., R.K. Horst, and R.W. Langhans.
1997. Use of Bicarbonates to inhibit in vitro colony growth of Botrytis cinerea. Plant Disease 81:1432-1438.

Salazar, A. 2001. Evaluación de la Actividad Fungicida de Dos Bicarbonatos y un Carbonato en Condiciones in vitro e in vivo. Tesis presentada para obtener el grado de Ingeniero Agrónomo. Escuela de Agronomía, Facultad de Ciencias Agrarias. Universidad de Talca. Talca, Chile. 48 p.

Punja, Z.K., and R.G. Grogan. 1987. Effects of inorganic salts, carbonate-bicarbonate anions, ammonia, and the modifying influence of $\mathrm{pH}$ on sclerotial germination of Sclerotium rolfsii. Phytopathology 72:635-639.

Wingwright, M. 1992. An Introduction to Fungal Biotechnology. Wiley and Sons. England. UK. $202 \mathrm{p}$.

Ziv, O., and A. Hagilady. 1993. Controlling powdery mildew in euonymus with polymer coatings and bicarbonate solutions. HortScience 28:124-126.

Ziv, O., and T.A. Zitter. 1992. Effects of bicarbonates and film-forming polymers on cucurbit foliar diseases. Plant Disease 76:513-517. 
